\title{
Nunavut calls inquest into record number of suicides
}

$\mathrm{N}$

unavut's chief corner has called for an inquest to focus attention on the overwhelmingly high rate of suicide in the territory, after 45 people took their own lives in 2013 - the highest number of annual suicides since the territory's creation in 1999.

Padma Suramala, a registered nurse and Nunavut's Chief Coroner, announced the inquest at a news conference on Jan. 16 in Iqaluit. She plans to convene a jury of six people to examine two or three of the deaths that occurred in 2013 , selected at random from the 45 suicides.

"We would like to highlight the risk factors and the warning signs, raise public awareness and make recommendations on how to prevent these preventable deaths," Suramala told CMAJ in an interview from Iqaluit.

The youngest person to take his own life in Nunavut last year was an 11year-old boy in Repulse Bay, and the oldest was 72 , Suramala says. There were 33 males and 12 females among the dead.

The 2013 suicide rate in Nunavut amounts to 156 deaths per $100000-$ 13.5 times the most recently available national data (2009) of 11.5 per 100000 .

The majority of those who committed suicide in the territory last year were young men between the ages of 15 and 25. Historically, this age cohort is at the highest risk. From 1999 to 2011, the suicide rate of Inuit males aged 15-19 was just over 500 per 100000 , according to statistics compiled from coroners' records by Jack Hicks, a researcher and $\mathrm{PhD}$ candidate studying Inuit suicide. The rate for nonInuit males aged 15-29 elsewhere in Canada is 12.6 per 100000 .

The number of completed suicides speaks to the larger issue of widespread suicidal ideation in the territory, says Natan Obed, director of Social and Cultural Development for Nunavut Tunngavik Inc., which oversees implementation of the Nunavut Land Claims

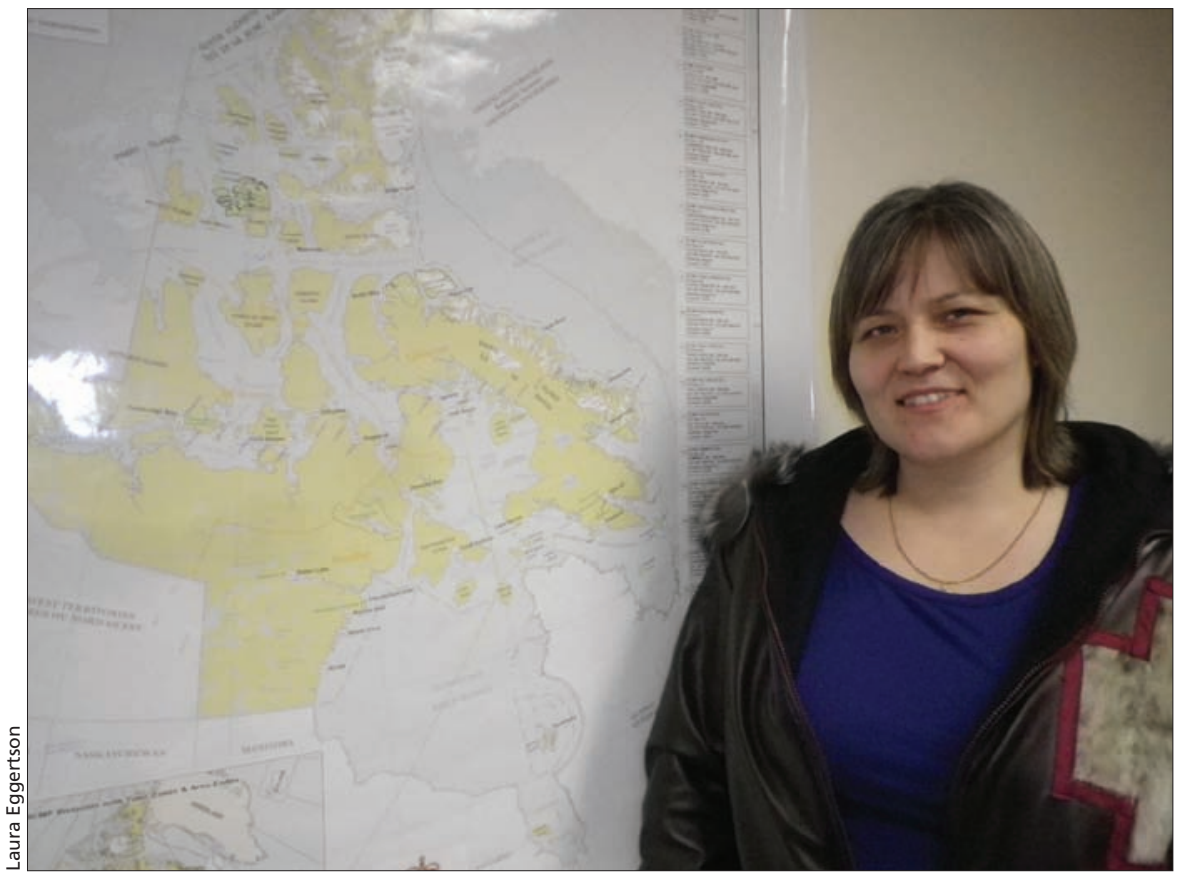

RCMP Sergeant Yvonne Niego, vice-president of a suicide prevention organization in lqaluit, says many of the young men who kill themselves lack hope.

Agreement. The Royal Canadian Mounted Police (RCMP) responded to 1120 suicide attempts last year, he added.

Both Obed and RCMP Sergeant Yvonne Niego, the community policing coordinator and vice-president of Nunavut's Embrace Life Council, pointed to a follow-back study that identified risk factors for suicide by examining the lives of 120 people who committed suicide between 2003 and 2006. The psychological autopsy found high rates of childhood sexual and physical abuse, depression, and alcohol and marijuana abuse in the personal histories of those who died. The study also highlighted the effects of historical trauma.

"This [inquest] is another layer of information that will help us identify ways to decrease suicidal ideation and to minimize the risk of suicide attempts," Obed says. He called on all the partners in the territory's suicide prevention strategy to use the information they have and that they will gain to mould interventions specific to the needs of Nunavummiut.
Obed emphasizes the need to provide a healthy foundation for children. "We need to ensure that children aren't being abused, whether physically or sexually. We need to make sure people understand the dangers of substance abuse. We need to have a better mental health system."

Nunavut's government is also keen to move forward. "We welcome learning anything more that we can about the causes of suicides in terms of informing how we can move forward in supporting Nunavummiut and reducing the incidence of suicide," Lynn Ryan MacKenzie, executive director of Mental Health and Addictions for Nunavut's Department of Health told CMAJ.

Finding the money and attracting and retaining qualified mental health practitioners are always a challenge, Ryan MacKenzie added.

The Embrace Life Council would welcome more national financial resources to supports its suicide prevention attempts, but they must be locally informed and culturally relevant, says 
Niego, who has responded to many suicides and suicide attempts.

In calling the inquest, Suramala is following the example of Ontario's Office of the Chief Coroner, which in 2011 released a review into a string of suicides in the Pikangikum First Nation. The review resulted in 100 recommendations for change. "This is going to serve a similar purpose, so that we can attract national attention and hopefully get more funds in order to implement many other facilities to help the youth suffering with mental health [conditions]," Suramala says.
Given Nunavut's small population of approximately 31000 , the deaths have a devastating impact on communities, from the family and friends of those who die to front-line workers.

Nunavut's 23 coroners are not immune to these effects, says Suramala. Often, coroners in local communities have to step down when a suicide occurs because they are related to the person who has died. Suramala then takes over the case; she has been closely involved in the inquiries into all 45 deaths.

"It's very disheartening and overwhelming to see the families grieving for their loved ones lost," Suramala says. "We as coroners are also human beings and it is affecting us as well as the families and the rest of the population."

Many of the young men who commit suicide are unemployed, and the youth who Niego speaks to say they need jobs, more positive role models, mentors and - critically - more hope. "I really would stress forward-thinking for building a sustainable future, which of course means no suicide," she says. - Laura Eggertson, Ottawa, Ont.

CMAJ 2014. DOI:10.1503/cmaj.109-4706 